\title{
Wanderings
}

\section{By canoe and microlight in Nepal}

\author{
MARY GANCZAKOWSKI
}

In the autumn of 1986 I was asked to accompany an expedition to Nepal. The plan was to canoe down a white water river, the Dudh Kosi, which flows from Everest, and to use microlights for reconnaissance and to support the river team. Microlights had never flown in Nepal and the pilots hoped to achieve new altitude records for this type of aircraft. My first task as expedition doctor was to write to various drug and medical supply companies asking for help. Almost all of them responded generously with donations of drugs, dressings, and vaccines.

We flew to Kathmandu in early September and spent a few days in the city organising our gear-canoeing equipment, microlights, film gear for the planned television documentary, and, of course, the medical kit. Eating in the local restaurants soon produced a crop of gastrointestinal symptoms requiring some medical intervention.

The Dudh Kosi starts at the confluence of three rivers along the well known Everest trek in eastern Nepal. The largest tributary has as its source the great Khumbu glacier of Everest and to get there we had at least 14 days of trekking ahead. One hundred and thirty porters and a cook team accompanied us.

On the first few days leeches abounded in the damp undergrowth. They were adept at finding access to clothing, injecting local anaesthetic into the skin so that attachment is unnoticed. As the leech sucks blood it produces hirudin, a non-enzyme inhibitor of thrombin, which prevents the blood meal clotting. When satisfied the leech detaches, but the anticoagulant in the wound results in prolonged bleeding. The first sign may be a blood soaked item of clothing, the leech having already left. If discovered, however, feeding leeches can be difficult to detach. The end of a lighted cigarette is most effective, causing instant release of the three suckers. Our team of fit sportsmen had few smokers, but our cameraman, trying to cut down with my constant warnings about his carbon monoxide levels and our increasing altitude, was able to put his cigarettes to a much more useful end.

After eight days we reached a small town called Lukla at $3000 \mathrm{~m}$. An airstrip enabled the two microlights to join us. We continued north towards Everest following the Dudh Kosi river, sometimes close to the bank viewing with awe the powerful white water and sometimes $1000 \mathrm{~m}$ above as the river cut through steep sided gorges.

\section{First sight of Everest}

Two days later we were at Nanche Bazar, the capital of the Sherpa area, in a wonderful setting at $3700 \mathrm{~m}$. At $350 \mathrm{~m}$ above the town is another small, now disused airstrip, which enabled us to liaise with the microlights again. I was lucky enough to be a passenger in one for a spectacular flight. Flying in these flimsy machinies in the unpredictable air currents of the Himalayas may be dangerous and I was mildly apprehensive as we revved up. Shortly after take off the ground dropped away abruptly as we flew over the edge of a gorge, the Dudh Kosi river $1000 \mathrm{~m}$ below. I closed my eyes and tried to relax, but any apprehension I had soon turned to exhilaration as I opened my eyes into the cold wind and saw Ama Dablam, a majestic and beautiful double peaked mountain. As we flew further up the valley a panorama of high peaks came into view including Everest. What a fabulous way to have my first sight of this mountain-from a microlight. We were also able to celebrate having achieved a new record for microlights-namely, taking off and landing with two people on board at $4000 \mathrm{~m}$.

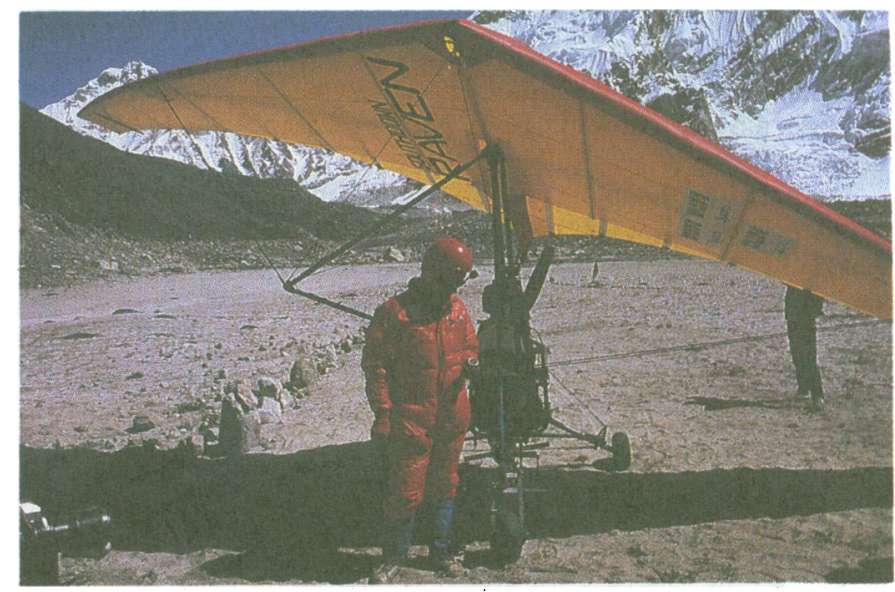

Simon Baker successfully landing by microlight at $5700 \mathrm{~m}$ near Everest.

\section{Problem of mountain sickness}

Mountain sickness was now a potential problem and our further ascent had to be gradual, with stops for acclimatisation. At $4500 \mathrm{~m}$ in the village of Pheriche there is a small hospital run by the Himalayan Rescue Association and manned by volunteer doctors for three months at a time. The centre was originally built for investigating and treating mountain sickness but it also serves as a clinic for passing tourists, expeditions, and the local population.

It is not fully understood which environmental changes lead to mountain sickness. Animal models suggest that the reduction in barometric pressure is more important than reduced oxygen tension, but both probably have a role. The first features are usually headache, nausea, and vomiting, but these may progress to pulmonary and cerebral oedema within a few hours. The best treatment is to descend to a lower altitude, but if this is impossible oxygen or dexamethasone can reverse the symptoms. Diuretics have also been used but may lead to hypotension without relief of oedema. Without action death may occur within a few hours. At $5500 \mathrm{~m}$ two of the team developed headache and nausea, which I treated with acetozolamide, aspirin, and antiemetics with rapid relief of symptoms. Acetozolamide, a carbonic anhydrase inhibitor, is thought to work by counteracting the alkalosis caused by increased ventilation at altitude. Another symptom that was reported by four team members was tingling and paraesthesia of hands and feet, which I also attributed to alkalosis causing reduction 


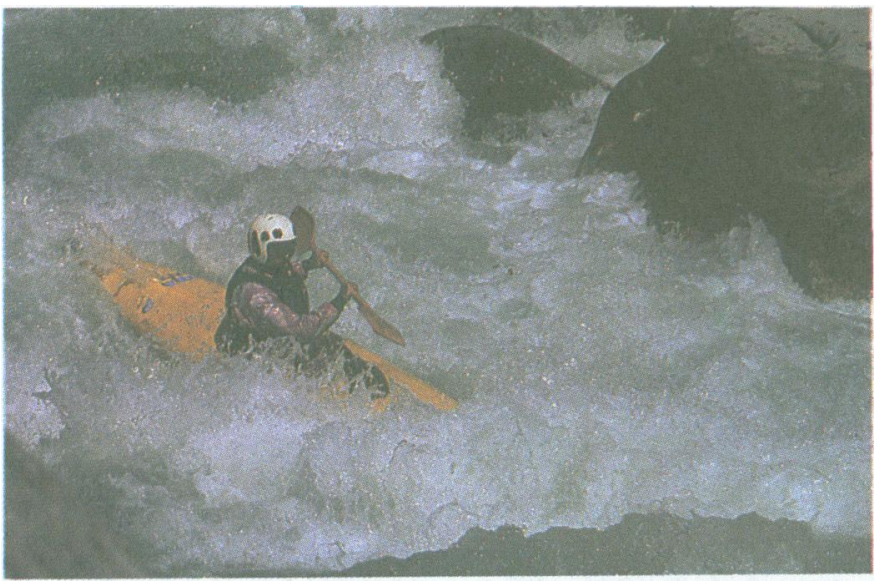

Canoeing down the Dudh Kosi.

in the ionised calcium concentration. The alkalosis may contribute to pulmonary and cerebral oedema by impairing the sodium pump mechanisms in the cell membranes.

Many of our porters lived at low altitudes and a few of them also developed headache and nausea, which I treated as above. Two porters descended because of persistent symptoms, but another who had not received any treatment went on to develop pulmonary oedema. His symptoms resolved rapidly on descent to a lower altitude, although he had to be carried part of the way down by two of his colleagues.

Walking further up the valley was now becoming a real effort with frequent pauses for breath. The river was becoming too shallow and rocky to canoe down, but we wanted to continue to the source of the river, the Khumbu glacier on Everest. At $5700 \mathrm{~m}$ on an icebound lake within the glacier itself three canoeists slid their boats into the cold water and paddled across the lake panting hard in the thin atmosphere.

\section{Champagne at high altitude}

To one side of the huge glacial tongue was a small settlement, Gorek Shep, where a dried up lake bed provided a flat sandy area ideal for another, yet higher, microlight landing. It was a difficult approach and we watched apprehensively as Simon Baker appeared at over $6700 \mathrm{~m}$, a tiny dot against the high masses of Nuptse and Everest. We were relieved as his wheels touched down and we were able to celebrate his landing by discovering how fast a champagne cork is ejected from the bottle when the barometric pressure is only about half of its value at sea level.

We descended to Pheriche again, where there was enough depth and flow of water in the river for the canoeists to begin their descent proper of the river. At this point it drops by over $125 \mathrm{~m}$ in a kilometre, continuous, unremitting, white water strewn with large boulders. Some of the team used "Bats," small canoes originally designed for use in swimming pools. The short length of these boats enabled high manoeuvrability through the rocks. The other main type of boat used was a slalom canoe appropriately called the "Everest." The longer, more pointed profile, although reducing manoeuvrability, did facilitate breaking out of "stoppers" and other turbulent stretches of water.

The plan was for the microlights to help in reconnaissance of the river in the gorges and less accessible areas. But after starting the descent of the river disaster struck. The exhaust on Simon Baker's microlight had cracked and so Dave Young had flown it back in his microlight for repair. On his return he was attempting to gain height as he approached Pheriche when a downdraught sucked him into the mountainside at the base of Mount Ama Dablam. The microlight smashed into the slope at about $120 \mathrm{~km}$ an hour, somersaulted several times, and disintegrated. Miraculously the pilot was able to crawl from the wreckage, but he was suffering from internal abdominal injuries. The crash occurred two weeks' walk away from the nearest road, but only about one hour away from the small hospital at Pheriche. The two doctors were soon on the scene and Dave was supported with intravenous fluids, analgesics, and antibiotics for the following 20 hours until he could be flown by helicopter to Kathmandu. At Patan hospital he underwent an emergency laparotomy, and two large perforations in his small bowel were repaired.

\section{White water paddling skills}

The canoeists now continued their descent without a flying eye to warn of problems to come. The river then entered a steep inaccessible gorge between Thyangboche and Namche Bazar. In the absence of adequate reconnaissance this section of the river was omitted and the canoeists re-entered the river beyond Namche. The river was now much bigger and to come out of a canoe or get trapped in a "stopper" in this powerful water was dangerous. Most of the canoeists, however, continued to give magnificent displays of their white water paddling skills with spectacular descents of incredible stretches of water.

Below Jubing the canoeists entered another gorge that was to prove much more difficult than any of them had expected. Believing this section would take only two or three days, they had set off unsupported with minimal supplies of food and clothing. Over the next few days they undertook some of the most difficult and dangerous canoeing of their lives. This section took nearly eight days. Where possible they climbed out of the gorge at night to find food and shelter from the local people, but they were becoming tired, hungry, and thin. On the last day, however, the river flattened out as it approached the confluence with the Sun Kosi river. Waiting there to greet and feed them were a Nepalese rafting team with three large inflatable rafts and the rest of the expedition members. The following day we all set off in rafts and canoes on this much broader and deeper river. The rapids interspersed with smoother, although fast flowing, water.

This part of the river descent was enjoyable for all; travelling in rafts enabled the rest of the team to experience big and exciting rapids and the canoeists could also relax and enjoy the river.

After the microlight crash we had sent for our reserve microlight pilot, Malcolm McBride. With the exhaust on the other microlight now repaired the two of them could join us on this part of the trip. There were often long sandy beaches along the river bank and the microlights had little problem finding suitable flat areas to land and liaise with us. They were able to perform aerial reconnaissance of the river and also bring in useful supplies.

After five days the river abruptly broadened and the land ahead was completely flat, in stark contrast to the mountains and hills behind us. We had reached the end of the Himalayas and the start of

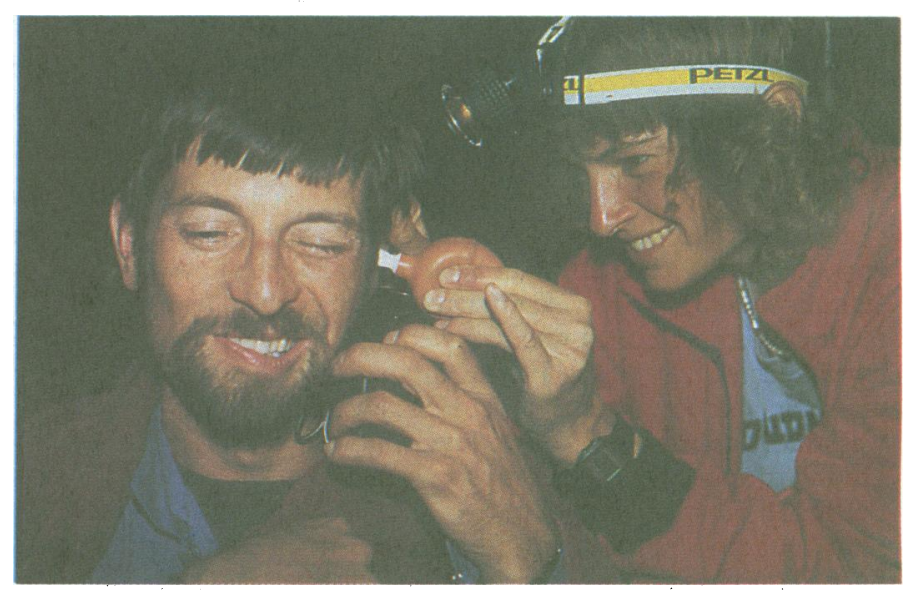

Removing wax from the ears of one of the expedition members. 
the vast Indian plain, which stretched for hundreds of miles in front. Here our expedition was to end and we were saddened that our existing trip was drawing to a close. We travelled back to Kathmandu by road and joined Dave Young, now out of hospital and recovering well from his injuries.

\section{Cameraman as well as doctor}

The trip was a memorable adventure for me. I had been fairly busy with the 12 team members and up to 130 porters. As well as illnesses there were many minor injuries, including bad bruises in a porter who had encountered an irritable yak on the trail. Local people also presented with more chronic problems, leg ulcers, eye infections, boils, and productive coughs.

Apart from my role as a doctor I was also assistant to the cameraman. I learnt techniques of sound recording and documentary film making, which was interesting and enjoyable, and the film we made, Thin Air White Water, was screened on Channel 4. My third major role was as stills photographer. The professional photographer we had planned to take had withdrawn at short notice, so official photography was designated to three of us with the most photographic experience. We have used the results for slide talks and to illustrate magazine articles about the expedition.

I thank Mr Mick Coyne for asking me to accompany the trip and Mr Nick Downie for teaching me about film making; Professor A V Hoffbrand for allowing me to take the leave; and Mrs Megan Evans for typing the manuscript.

Royal Free Hospital, London NW3 2QG

MARY GANCZAKOWSKI, BSC, MRCP, senior registrar in haematology

\title{
The forgotten war in the hidden valley
}

\author{
H D W POWELL
}

The Balkan Airways flight left Heathrow early afternoon on a Saturday in mid-March, first stop Sofia. Here we had a lengthy wait before travelling on. The Russian aeroplane was efficient but drab. Sofia Airport transit lounge has a marble floor, chandelier lights, and just basic tables and chairs. But on the lower floor is the cheapest duty free in Europe--not much good if you are flying to an Arabic country. We were-via Cairo and in an aeroplane with steadily decreasing occupancy. We landed at Khartoum at $330 \mathrm{am}$ and all $\mathbf{4 0}$ of us got off. Khartoum Airport was little changed since I was last there in 1971 and slow. We finally reached the Acropole Hotel and welcome beds as it grew light.

This trip was the first by a United Kingdom medical team to visit Eritrea. Two orthopaedic surgeons from Britain had been beforePeter Webb from Great Ormond Street and Robert Duke from Warwick, as well as a few orthopaedic visitors from various countries of western Europe. In March 1987 a whole medical team was asked to visit and our travelling was funded by International Medical Relief.

The Eritrean People's Liberation Front has been engaged in a struggle for independence against Ethiopia since 1961, and in 1981 it set up a base hospital of 1200 beds at Orotta. To work at Orotta was the genesis of our team's visit, and arrangements via International Medical Relief were made by the Eritrean Relief Association.

In Khartoum the relief association took over, dealing with police permits and arranging our flights to Port Sudan on the Red Sea. Woken at 430 am on the Tuesday we made the flight by two minutes; airline ticket arrangements had gone awry. Port Sudan was hot, breezy, and sandy. The association's guest house was our home for the next four days. Delay in travelling on was caused by the second and Unity Congress of the Eritrean People's Liberation Front and the Eritrean Liberation Front. (Years ago the two were in conflict.) This congress, attended by a worldwide audience, was in a specially built auditorium holding 2800 people and we could not travel into Eritrea until this was finished.

We finally arrived seven days after leaving London. Three quarters of an hour on a fast road in a Toyota Land Cruiser to Suakim, the old Turkish slaving port, where a massive vehicle repair camp occupies acres of sand. From then on the "road" is sand, rock, dry river bed, and wet river bed. Eleven hours at an average speed of $14 \mathrm{~km}$ an hour, almost always in second or third gear, rarely fourth, not infrequently first, and sometimes in four wheel drive. The flat desert country of the eastern Sudan was enlivened by a small locust swarm, creatures with bodies at least $6 \mathrm{~cm}$ long and leaping up to a metre or more in front of the vehicle. It was dark when we reached the drivers' camp for baked bread and jam and crossed a large dry river bed. In moonlight the country continued like a moonscape; mice and rabbits crossed the track and gradually we climbed.

\section{Gentle questions at the "frontier"}

Starting to splash up a wet river valley we climbed more, reaching the Eritrean checkpoint to be gently questioned at the "frontier"-name, country, and occupation. Orthopaedic surgeon was documented. Nurse was easy, but physiotherapist posed a linguistic problem, and prosthetist was I am sure beyond the guardsman. Then past three "camps" for Ethiopian prisoners of

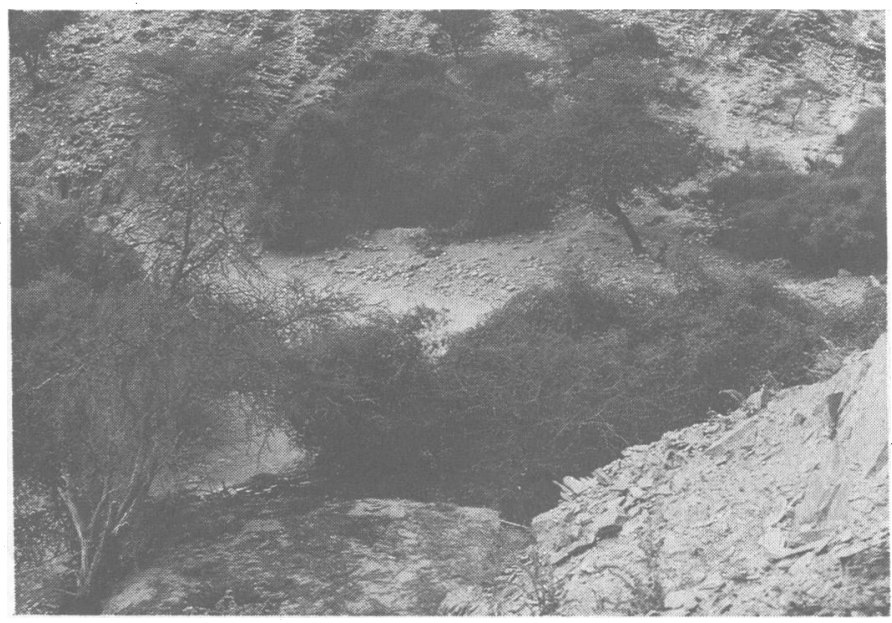

The medical guest house is under the nearest thorn tree and its cookhouse under the far one. 